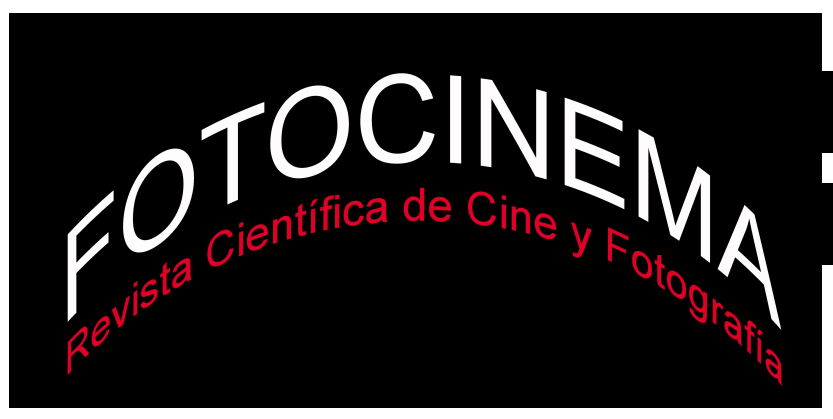

\title{
Por las sendas argentinas. Un derrotero por el cine político-militante de Raymundo Gleyzer
}

\section{For the argentine paths. A course through the political - militant cinema of Raymundo Gleyzer}

\author{
Charo López Marsano \\ Universidad de Buenos Aires, Argentina \\ lopezmarsano@gmail.com
}

\section{Resumen:}

Raymundo Gleyzer, cineasta argentino desaparecido en mayo de 1976, dejó una vasta producción que combina el documental con la ficción. Atravesado por los preceptos del Cinema Novo proclamaba que "para hacer cine, solo se necesita una cámara en mano y una idea en la cabeza”. Como alma mater del Cine de la Base compartía con sus colegas de Cine Liberación la idea del cine como herramienta de contrainformación. Más pragmático que intelectual, dejó escasos escritos sobre sus reflexiones en torno al tercer cine o a la construcción de un nuevo lenguaje. Sin embargo, en ocasión de la presentación de su film Los Traidores, durante la $I X$ Muestra Internacional del Nuevo Cine de Pésaro en 1973, dejó sentada su posición sobre la eficacia del cine revolucionario latinoamericano. No sólo destacó entonces algunos rasgos comunes pregonados por el cine militante, sino que enfatizó la importancia del videotape como herramienta para la difusión de los films en el ámbito latinoamericano. Asimismo, al defender su decisión de apelar a la ficción clásica para narrar su historia, puso en el ojo de la tormenta el debate sobre el lenguaje cinematográfico al interior del cine político europeo.

\begin{abstract}
:
Raymundo Gleyzer, an Argentine filmmaker who disappeared in May 1976, left a vast production that combines documentary with fiction. Crossed by the precepts of Cinema Novo, he proclaimed that "to make movies, you only need a camera in hand and an idea in the head". As alma mater of the Cine de la Base, he shared with his colleagues at Cine Liberación the idea of the cinema as a tool for counter-information. More pragmatic than intellectual, he left few writings on his reflections on the third cinema or the construction of a new language. However, on the occasion of the presentation of his film Los Traidores, during the IX Pesaro International Film Festival of New Cinema in 1973, he sets out his position on the effectiveness of Latin American revolutionary cinema. Not only did he highlight some common features preached by the militant cinema, but he also emphasized the importance of videotape as a tool for the diffusion of films in the Latin American context. Also, in defending his decision to appeal to classical fiction to tell his story, he put in the eye of the storm the debate on the cinematographic language within European political cinema.
\end{abstract}

Palabras clave:

Tercer Cine; cine político-militante; Raymundo Gleyzer; desaparecido; Cine de la Base.

Keywords:

Third Cinema; political-militant cinema; Raymundo Gleyzer; missing; Cine de la Base. 


\section{Introducción}

Durante el período 1955-1976, la sociedad argentina atravesó una situación de empate hegemónico difícil de resolver. En ese contexto, la radicalización social y política fue en aumento, expresándose tanto en la emergencia de nuevos actores como en sus formas de militancia ${ }^{1}$. Un espíritu revolucionario se puso de manifiesto en el ámbito de la cultura, dando origen en el plano cinematográfico a un cine político de carácter diverso. Si bien este ethos se plasmó a escala mundial, las características que asumió en Argentina fueron particularmente idiosincráticas y estuvieron atravesadas por los acuerdos/discrepancias existentes entre quienes adherían al peronismo combativo y quienes se inscribían en las corrientes de la Nueva Izquierda. Desde ambas vertientes político-ideológicas nacerá hacia 1968 un nuevo cine de carácter militante, cuyo principal objetivo fue la denuncia y la contrainformación ${ }^{2}$. Allí debe ubicarse el surgimiento del movimiento del tercer cine argentino, que puso énfasis en la categoría de cine-acto, plasmada por Octavio Getino3 en Hacia un Tercer Cine. En su manifiesto subyacía conceptualmente la idea del cine como acto inacabado, fruto siempre parcial, sujeto a un proceso de permanente construcción/reconstrucción. El cine-acto se constituía así en una apuesta política de carácter colectivo, donde los roles del productor/realizador y del espectador/actor se desdibujaban, se mezclaban, se complementaban en una

\footnotetext{
${ }^{1}$ La situación de empate hegemónico en Argentina durante dicha etapa, tuvo origen en el golpe de Estado que derrocó al presidente Juan Perón en septiembre de 1955. Desde entonces y hasta su vuelta al poder en 1973 el peronismo estuvo proscripto. Tres años más tarde, el 24 de marzo de 1976, fue nuevamente derrocado. La creciente radicalización social y política se profundizó con la instauración de la dictadura autodenominada Revolución Argentina, en septiembre de 1966. En dicho contexto, la proscripción y la represión se extendieron más allá del peronismo o el comunismo alcanzando al conjunto de la sociedad.

2 En concordancia con Mariano Metsman y en función del planteo historiográfico hasta aquí expresado, considero que el espíritu rupturista e "icónico" del 68 se inscribe en una larga duración que, en cada país, se halla atravesada por su propia idiosincrasia política, económica y cultural. Casualmente, en el caso argentino dicho año coincide con el estreno de la obra pionera del cine político-militante: La Hora de los Hornos (Getino y Solanas, 1968). Véase: Metsman, 2016.

3 Cineasta argentino que fuera miembro fundador, junto a Fernando Solanas, del Grupo Cine Liberación en 1968, grupo de cineastas militantes vinculados a la CGTA y al movimiento peronista. Su planteo de un cine para la "descolonización cultural" y puesto al servicio de la "liberación" de los países del Tercer Mundo era tanto una crítica al primer cine de estilo hollywoodense, como al segundo cine o cine de autor. Véase: Getino, 1998 y Stam, 2001.
} 
tarea de descolonización cultural. Fue en el seno de dicho movimiento donde destacaron los grupos Cine Liberación 4 y Cine de la Base ${ }^{5}$.

Raymundo Gleyzer, cineasta argentino detenido-desaparecido el 27 de mayo de 1976, dejó una vasta producción que combina el documental con la ficción. Atravesado por los preceptos del Cinema Novo proclamaba que "para hacer cine, solo se necesita una cámara en mano y una idea en la cabeza”. Como alma mater del grupo Cine de la Base compartía con sus colegas de Cine Liberación la idea del cine como herramienta de contrainformación. Más pragmático que intelectual dejó escasos escritos formales sobre sus reflexiones en torno al tercer cine, la construcción de un nuevo lenguaje o la importancia del circuito popular/alternativo de exhibición. Lo que conocemos acerca del grupo y sus posicionamientos proviene de los testimonios legados por los protagonistas de esa experiencia ${ }^{6} \mathrm{y}$, sobre todo, del cuidadoso trabajo de conservación/preservación realizado por su esposa Juana Sapire7. En dicho archivo se reúnen copias de su obra fílmica, notas periodísticas, contratos y $\operatorname{cartas}^{8}$ que Gleyzer intercambiaba con referentes del ámbito cinematográfico local e internacional.

\footnotetext{
4 Sus integrantes se vinculaban con diferentes expresiones del peronismo combativo y actuaron orgánicamente como grupo entre 1968 y 1973. Véase: De la Puente, 2007 y Metsman, 1993.

5 Cine de la Base nace oficialmente como grupo en 1973. Sin embargo, sus producciones clandestinas datan de 1971. Sus miembros estaban políticamente comprometidos con el Partido Revolucionario de los Trabajadores-Ejército Revolucionario del Pueblo (PRT- ERP), de tendencia trosko-guevarista. Algunos llegaron a incorporarse a los frentes políticoculturales de masas del partido adhiriendo primero a la experiencia del Frente Antiimperialista de Trabajadores de la Cultura (FATRAC), un nucleamiento de artistas e intelectuales para impulsar expresiones política-culturales de la guerra revolucionaria, y posteriormente al Frente Antiimperialista y por el Socialismo (FAS). Véase: De la Puente, 2007, Longoni, 2006 y Seoane, 1997.

${ }^{6}$ La lista de testimonios es larga y diversa. Véase: Peña y Vallina, 2006; Sapire y Sabat, 2017; Ardito y Molina, 2003 y 2011.

7 Juana Alicia Sapire fue también miembro fundador del Cine de la Base. Trabajó junto a Raymundo primero como asistente en Ceramiqueros de Traslasierra y Pictografías del Cerro Colorado, ambas de 1965, y luego como sonidista de varios de sus films como Notas para Telenoche; México, la Revolución Congelada y Ni Olvido, Ni Perdón. Estos trabajos datan del período 1969-1973. Incluso, llegó a manejar la cámara cuando juntos viajaban por el mundo y Raymundo Gleyzer aparecía en campo fungiendo la función de cronista/entrevistador. Véase, Sapire y Sabat, 2017.

${ }^{8}$ La correspondencia, en tanto acto de intercambio epistolar, es un documento valioso en la reconstrucción del ideario de un documentalista como Gleyzer. Sus biógrafos nos acercan fragmentos de las cartas que intercambió con Miguel Littin, con miembros del colectivo boliviano Ukamau y con el cineclubista mexicano Carlos de Hoyos entre otros. Todas nos aportan información sobre su mirada cinematográfica. Véase: Sapire y Sabat, 2017.
} 
Por otro lado, sus participaciones en el circuito de festivales, donde Gleyzer presentó tanto sus films como su perspectiva en torno a la función del cine en aquel contexto, son otros documentos valiosos para bucear en su mirada, sus aportes y las discusiones que generaba. Asimismo, la Entrevista a Raymundo Gleyzer realizada por Peter Schumann para la televisión alemana en el verano de 1974 es fundamental para asomarse a sus objetivos políticocinematográficos en el marco del tercer gobierno peronista. De hecho Gleyzer y los miembros de Cine de la Base tenían una visión crítica del peronismo proveniente tanto de sus posicionamientos político-ideológicos previos, como de la línea política del PRT-ERP9 a la que entonces adherían. No obstante, es dable aclarar que sus principales críticas recaían en la figura de Perón, su esposa Isabel y los sectores de derecha nucleados en la Triple $\mathrm{A}^{10}$. No escapaban a las mismas los dirigentes sindicales burocratizados. Diferente era su postura frente a las corrientes militantes del peronismo combativo con quienes compartió experiencias, puntos de vista e incluso relaciones de amistad $^{11}$, tanto durante la etapa de la dictadura de la Revolución Argentina como durante la corta, heterogénea y conflictiva experiencia constitucional peronista (1973-1976). Cabe recordar que las rispideces con los miembros de Cine Liberación empezaron recién a tornarse complejas desde 1973 y se profundizaron, hasta la ruptura, en 1974.

El presente artículo versa tanto sobre la experiencia político-cinematográfica de Raymundo Gleyzer, como sobre su filmografía. En mi opinión resulta imposible tomarlas separadamente porque entre el compromiso político

\footnotetext{
9 El Partido Revolucionario de los Trabajadores, fundado en 1965, fue fruto de la fusión de dos agrupaciones políticas: el Frente Revolucionario Indoamericano Popular (FRIP) liderado por Mario Santucho y Palabra Obrera (PO) dirigido por Hugo Bressano, más conocido por el seudónimo de Nahuel Moreno. La posición de ambos líderes en torno de la lucha armada fue central en la división que se produjo en el partido hacia 1968. Así se constituyeron dos fracciones: PRT-La Verdad liderada por Moreno y PRT-el Combatiente liderada por Santucho. Este último grupo, fue la punta de lanza para la fundación del brazo armado del partido, el Ejército Revolucionario del Pueblo (ERP) en 1970. Veáse: Carnovale,2010 y Seoane,1997.

10 La Triple A (Alianza Anticomunista Argentina) fue un grupo paramilitar de extrema derecha creado en el seno del tercer gobierno peronista a instancias del entonces ministro de Bienestar social José López Rega. Vinculado a la derecha partidaria y a la Policía Federal fue responsable del asesinato, tortura y masacre de intelectuales y militantes de izquierda peronista y no peronista. Véase: González Janzen, 1986.

${ }^{11}$ La relación que lo unía con Humberto Ríos, Dolly Pussi y Edgardo "Cacho" Pallero así lo demuestra. Véase: Ardito y Molina, 2003 y 2011.
} 
revolucionario de Gleyzer y su cámara existió, desde temprano, una relación indisoluble. Analizar su obra desde una perspectiva historiográfica es pues tan útil como fundamental, no sólo para bucear en el rol del cine políticomilitante en un contexto de radicalización política, sino también para evaluar su impacto en la Argentina de entonces. Asimismo, esta perspectiva sirve para reflexionar acerca de las actualizaciones cambiantes que de aquellas propuestas se vienen realizando desde los orígenes de la transición democrática en 1983 hasta la actualidad.

\section{El hombre de la cámara}

Raymundo Gleyzer nació en el seno de una familia judía el 25 de septiembre de 1941. Sus padres eran actores del teatro independiente y adherentes al Partido Comunista. A partir de la emergencia del peronismo en 1945, y siguiendo la línea del PC, se convirtieron en fervorosos opositores al gobierno. Hacia 1954, tras la separación de sus progenitores, Gleyzer, con apenas 13 años, decidió salir a trabajar. Munido de su cámara fotográfica Leika comenzó a dedicarse a la fotografía de eventos sociales para contribuir a la alicaída economía familiar. Así, desde pequeño fue convirtiéndose, al mismo tiempo, en un obrero y un artista de la imagen. Al finalizar sus estudios secundarios en 1960 inició un curso de fotografía profesional al tiempo que estudiaba realización cinematográfica en un instituto particular y se vinculaba al ambiente del cineclubismo. Paralelamente, ingresó en la Facultad de Ciencias Económicas de la Universidad de Buenos Aires (UBA).

Sin embargo, su deseo era abocarse a una carrera afín al arte fotográfico y cinematográfico y trasladarse a Santa Fe donde funcionaba el Instituto de Cinematografía, dependiente de la Universidad Nacional del Litoral (UNL), fundado por Fernando Birri en 1956. No obstante, su situación personal/familiar, que no era holgada, lo mantenía sujeto a Buenos Aires. Optó finalmente por la Escuela Nacional de Bellas Artes de la Universidad Nacional de La Plata (UNLP), a donde llegó a comienzos de 1962 permaneciendo hasta 1964. Ese año filmó La Tierra Quema, un cortometraje documental de denuncia social donde retrataba la miseria en el Nordeste 
brasileño. Poco después, no sólo abandonó su trabajo de fotógrafo social, sino que dejó la carrera para abocarse definitivamente a sus proyectos de cine independiente ${ }^{12}$.

La Tierra Quema, junto a otras producciones posteriores como Ceramiqueros de Traslasierra (1965), Pictografías de Cerro Colorado (1965) y los documentales que filmó junto a Jorge Prelorán, Ocurrido en Hualfin (1965) y Quilino (1966), fueron el punto de arranque de una filmografía de carácter bioetnográfico que suele agruparse bajo la nominación de películas de la tierra. En todas ellas, Gleyzer despliega el profundo sentido sociopolítico con que conduce su cámara; la misma no sólo registra, sino que devela dejando al descubierto el objetivo de su búsqueda, de su mirada, centrada en la denuncia de las condiciones de desolación/explotación de los más débiles.

Sus biógrafos señalan la existencia de un cortometraje previo a los films de la tierra, supuestamente fechado en 1963, intitulado El Ciclo y del cual suelen destacarse dos aspectos. Por un lado, cierta influencia de Michelangelo Antonioni y, por otra parte, cierto rechazo de Gleyzer al mismo. Esto podría obedecer a que el corto no poseería ni un fondo, ni una forma estética narrativa como la que se hace presente en sus films posteriores, donde la preocupación por lo sociopolítico guia sus tramas. Sin embargo, a mi juicio, esta apreciación es relativa dado que las referencias que se hacen en la película a enfrentamientos políticos entre sectores de izquierda y del grupo derechista "Tacuara" constituyen en dicho contexto una verdadera denuncia política por parte de Gleyzer. Es más, no se trata de una denuncia cualquiera sino de la mirada de un adherente al PC, también judío y profundamente detractor del peronismo o por lo menos de ciertos grupos de derecha con que se lo vinculaba.

\footnotetext{
12 Raymundo Gleyzer sentía una particular atracción hacia el cine documental social que se desarrollaba, de la mano de Fernando Birri, en la Universidad del Litoral. En tal sentido, la Universidad de la Plata, con un perfil más dirigido al cine de ficción y a los lineamientos de la Industria Cinematográfica, acabó por no colmar sus expectativas. Véase: Ardito y Molina, 2006 y 2011.
} 
Lo cierto es que El Ciclo suele aparecer como el primer film de Gleyzer, dado que habría sido rodado en 1963. Sin embargo, un análisis cuidadoso del guion y de ciertos hechos históricos que los personajes mencionan casi como al azar, revela que existe un error en la supuesta fecha de filmación ya que en el mismo se alude a sucesos ocurridos en las ciudades de Rosario y Buenos Aires entre el 23 y el 29 de febrero de 1964. Me refiero concretamente al enfrentamiento en un plenario de la CGT en Rosario entre sectores de izquierda (ligados al PC y presuntamente al "Ejército Guerrillero del Pueblo") y grupos de militantes peronistas de derecha nucleados en "Tacuara". En represalia por los muertos que tuvieron ese día, un grupo de tacuaristas cobró venganza asesinando unos días más tarde al militante comunista Raúl Alterman en la puerta de la casa de sus padres en el barrio porteño de Once. Sin embargo, sus biógrafos en general y Juana Sapire en particular suelen poner énfasis en que Raymundo Gleyzer "prefería desconocer este primer film y colocar en ese sitio a La Tierra Quema”. Más allá de sus deseos, el corto existió, posee un claro componente político y, de acuerdo a los datos históricos que aquí aporto, sólo pudo filmarse después del asesinato de Alterman acaecido el 29 de febrero de 1964. Ahora bien, según el registro de sus biógrafos, Gleyzer estuvo en el Nordeste brasileño filmando La Tierra Quema por lo menos entre fines de octubre de 1963 y fines de marzo de 1964, cuando se produjo el golpe de Estado de Castelo Branco contra el gobierno de Joao Goulart. De modo que la fecha de realización de El Ciclo es, necesariamente, posterior a marzo de $1964^{13}$.

Hacia 1966, Gleyzer empezó a trabajar como cronista de televisión para el noticiero "Telenoche" que se emitía por Canal 13 de Buenos Aires. De esa experiencia surgieron una serie de notas periodísticas entre las que se destacan Nuestras Islas Malvinas (1966), Mataqué (1967) y Nota sobre Cuba (1969). Esta última formó parte de una experiencia más amplia que realizaron Gleyzer y Sapire entre 1967 y 1969 para la División Noticias de Proartel que se llamó Viajando por el Mundo. Además de la nota enviada desde Cuba, Raymundo Gleyzer y Juana Sapire produjeron otras desde

${ }^{13}$ Acerca de "Tacuara", véase: Gutman, 2003. 
Bulgaria, Yugoslavia, Grecia, Checoslovaquia y Suecia. Tres de estos países formaban parte del bloque socialista europeo y estaban atravesados por los efectos provocados por el fin del "deshielo soviético" desde el ascenso de Brezhnev en $1964^{14}$. Así pues, el contraste percibido entre la experiencia socialista europea y la latinoamericana, terminaron de consolidar en Gleyzer sus tendencias guevaristas y su adhesión a la Revolución Cubana. El viaje a Cuba fue el engranaje que faltaba para desencadenar un cambio drástico en su forma de ver y entender la Revolución Socialista. Ese será el comienzo de sus contactos con el PRT/ERP y su vinculación al Frente Antiimperialista de Trabajadores de la Cultura (FATRAC), donde conoció a dos de los miembros del futuro Cine de la Base, Álvaro Melián y Nerio Barberis.

Un año más tarde, la experiencia mexicana constituirá una bisagra en su carrera cinematográfica. La filmación de México. La Revolución Congelada (1970) será la punta de lanza de su apuesta definitiva de un cine por el socialismo ${ }^{15}$. Ese mismo año, a su regreso a la Argentina, intentó avanzar en un proyecto colectivo y latinoamericanista de cine revolucionario. Para ello elaboró proyectos para filmar en Chile y en Bolivia pero los mismos se vieron frustrados. Sin embargo, más allá de ese traspié, lo destacable es su persistencia y el sentido profundo que le atribuía al cine como arma revolucionaria. Entre 1971 y 1974 rodó una serie de films atravesados por esta premisa, entre los que cabe destacar los Comunicados del PRT-ERP (1971), Ni olvido, ni perdón (1972-73), Los Traidores (1972-73) y, el que fuera su último film, Me matan si no trabajo y si trabajo me matan (1974). Paralelamente, siguió presentando su obra en el circuito de festivales y sobre todo, a partir de Los Traidores, lo hizo subrayando el carácter colectivo de su producción. Al respecto es sumamente elocuente el testimonio de Lino Micciché quien a propósito de la actitud de Raymundo Gleyzer durante la $I X$

14 Tras la muerte de Stalin en 1953, en el marco del proceso de desestalinización, Jruschov inició la política del "Deshielo Soviético" (1956-1964), que implicó un relajamiento parcial de la represión y la censura e impactó de forma diversa en los distintos países del bloque y más allá de él. Con la llegada de Brezhnev al poder soviético en 1964 el proceso se detuvo, afectando cierta autonomía que habían asumido algunos países de Europa oriental. En ese contexto, la invasión soviética de Checoslovaquia el 20 de agosto de 1968, conocida como Primavera de Praga, se convirtió en la punta de lanza de la doctrina Brezhnev para el área. 15 Nada más elocuente que la propia voz de Gleyzer al respecto. Véase: Gleyzer, 1970. 
Muestra Internacional del Nuevo Cine de Pésaro en 1973, donde se presentó el film, señaló:

No había en él ningún narcisismo subjetivo, ningún culto de sí mismo como autor. Era consciente de desarrollar un rol político y lo desarrollaba con gran dignidad (...) En Pésaro participó en un debate sobre la Argentina, a propósito del filme, no sobre el filme (Metsman, 2001a, p. 12).

En esa ocasión, dejó sentada su posición acerca de la eficacia del cine revolucionario latinoamericano y, amén de destacar algunos rasgos comunes pregonados por el cine militante, puso énfasis en la necesidad de utilizar medios de alcance popular como la fotonovela y el videotape con el fin de llegar a la base. Con el mismo sentido, defendió su decisión de apelar a la ficción clásica para narrar su historia y puso en el ojo de la tormenta el debate sobre el lenguaje cinematográfico al interior del cine político europeo. Indudablemente para Gleyzer la liberación estaba en la base. Nada ilustra mejor ese sentido que el siguiente relato de Fernando Birri:

Estábamos en Italia. Raymundo me fue a ver y recuerdo aquello como un momento de gran soledad compartida. [...] En nuestro trabajo [...] toda nuestra atención estaba colocada en el momento mismo de la producción [...] en tratar de ser un punto de resistencia en un ambiente totalmente hostil [...] sobre esos lineamientos trabajábamos nosotros y buena parte del cine latinoamericano. Pero esa tarde Raymundo me dijo: "Mirá, Fernando: creo que en ese sentido nos hemos equivocado porque hubiéramos tenido que empezar por el final”. Creo que este es su gran aporte, el final era el público [...] no entendido como destinatario ideal de la película [...] sino como posibilidad real desde la génesis del proyecto. Nosotros pensábamos en el público desde el campo, y él, desde el contracampo: dio vuelta el telescopio [...] colocó al espectador en el comienzo mismo del proceso de realización de sus films. (Peña y Vallina, 2006, p.122).

Ese fue sin duda el sentido y fin de Cine de la Base, un colectivo pensado para llegar al pueblo a través de una experiencia cinematográfica compartida. Formado a comienzos de 1973 por Raymundo Gleyzer, Juana Sapire, Álvaro Melián y Nerio Barberis, hacia 1974 el grupo se fue ampliando con la incorporación de Jorge Denti, Jorge Santa Marina, Leopoldo Nacht y Jorge 
Giannoni ${ }^{16}$ entre otros. Organizaban las proyecciones pensando en los materiales que mayor aceptación tenían entre los grupos con los que se vinculaban. Según ellos mismos, el grueso de las proyecciones versaba en torno a su película Los Traidores, o bien a Operación Masacre de Jorge Cedrón, aunque este último no era integrante del grupo. Asimismo, difundieron activamente tanto la obra colectiva de los Realizadores de Mayo, titulada Argentina, Mayo de 1969: los caminos de la liberación, como el mediometraje de Enrique Juárez, Ya es tiempo de violencia (ambas sobre la pueblada conocida como el Cordobazo ${ }^{17}$ ).

En el momento de mayor auge se llegaron a articular catorce grupos de exhibición de Cine de la Base distribuidos en siete provincias ${ }^{18}$. Todos contaban con proyectores y copias de las películas y realizaban encuentros cada semana en barrios, villas y/o sindicatos. Inclusive llegaron a contar con una sala de cine propia, construida con materiales muy precarios en la villa de "Camino Negro" en el Partido de Lomas de Zamora. Llegados a este punto, no está de más aclarar que si bien es cierto que el grupo Cine Liberación había sido pionero en la idea de hacer eje en el rol que debía asumir la exhibición del cine militante, la apuesta que guió a Cine de la Base poseía en el contexto de su desarrollo un sentido diferente, que debe mensurarse en términos de clase, dada la intención siempre presente en el grupo de dirigirse prioritariamente a sectores obreros y populares ${ }^{19}$.

\footnotetext{
${ }^{16}$ Jorge Gianoni dirigió la Cinemateca del Tercer Mundo dependiente de la Universidad de Buenos Aires (UBA) hasta septiembre de 1974.

${ }_{17} \mathrm{El}$ "Cordobazo" fue una insurrección popular que estalló en la ciudad de Córdoba los días 29 y 30 de mayo de 1969 liderada por Elpidio Torres (SMATA) y Atilio López (UTA), ambos pertenecientes a la Confederación General del Trabajo (CGT), y Agustín Tosco del sindicato de Luz y Fuerza, perteneciente a la CGT de los Argentinos (CGTA). Junto con el "Rosariazo" fue el comienzo de una serie de puebladas que marcaron el inicio del fin de la dictadura militar.

18 Cuatro de ellos en Buenos Aires y el resto en La Plata, Bahía Blanca, Trelew, Córdoba, Santa Fe, Rosario, Paraná, Corrientes y Chaco.

19 Existían diferencias temporales y/u organizativas que separan la experiencia de las Unidades Móviles del Cine Liberación entre 1968/1973 y la de los Grupos de exhibición del Cine de la Base desde 1973. Si bien ambos se desarrollaron de manera clandestina, Cine Liberación lo hizo en el marco de la dictadura de la Revolución Argentina, mientras que Cine de la Base tuvo como telón de fondo al Tercer gobierno peronista. Véase: Metsman, 2001.b y Peña y Vallina, 2006.
} 


\section{De lenguajes, registros y miradas ${ }^{20}$. Pensando el cine de Raymundo Gleyzer}

La fotografía y el cine fueron desde temprano los medios de expresión y militancia de Gleyzer. Desde 1963 y hasta su desaparición el 27 de mayo de 1976 no dejó de filmar, de pensar, de debatir, de mirar la vida con ojos cinematográficos. No sólo dirigió proyectos propios, sino que acompañó las producciones de otros cineastas como sonidista ${ }^{21}$ y/o camarógrafo ${ }^{22}$. Realizó un registro filmado de la obra Marabunta de Narcisa Hirsch y, hasta 1971, participó de varios proyectos institucionales (privados o estatales) para ganarse el sustento ${ }^{23}$. Paralelamente, fue filmando sus propios trabajos enumerados en el apartado anterior.

Salvo en El Ciclo y en Los Traidores donde apeló al relato ficcional, todo el resto de su producción se centra básicamente en el cine documental. Si bien toda su obra estuvo atravesada por una persistente apuesta sociopolítica, esta se despliega plenamente hacia 1970. En ese sentido, México. La Revolución Congelada es un punto de clivaje en su carrera y divide aguas en su producción cinematográfica. Desde entonces, Gleyzer asume plenamente la idea del cine como herramienta por y para la revolución, recuperando para siempre la frase de Ernesto Che Guevara que reza que "la Revolución será socialista o será una parodia de revolución”.

Dentro del campo cinematográfico, los integrantes de Cine de la Base marcaban como sus principales referentes al holandés Joris Ivens y al cubano Santiago Álvarez. No obstante, en toda la filmografía de Gleyzer han anidado múltiples influencias ${ }^{24}$. En lo que al registro y al lenguaje utilizado en sus producciones documentales se refiere, Raymundo Gleyzer operaba tanto con

\footnotetext{
${ }^{20} \mathrm{El}$ marco teórico utilizado para el análisis del lenguaje y registro cinematográfico en la filmografía de Gleyzer fue tomado/elaborado a partir de: Monterde Lozaya, 2016; Nichols, 1997 y Ortega, 2008.

${ }^{21}$ Tal el caso de Pescadores (1968) de Dolly Pussi.

${ }^{22}$ En la Hora de los Hornos (1966-1968) de Fernando Solanas y Octavio Getino manejó la cámara en la secuencia del Di Tella. Hizo lo propio en El Búho (1974) y Adiós Sui Generis (1975). Ambas de Bebe Kamín.

${ }^{23}$ Gleyzer prefería este tipo de trabajos ya que se negaba a poner su cámara al servicio de la publicidad.

24 Desde Antonioni en El Ciclo, el Cinema Novo en La Tierra Quema, y la mirada políticoideológica de los cineastas soviéticos en México. La Revolución Congelada.
} 
recursos propios del Cine Directo como del Documental de Reconstrucción. La decisión de apelar a este último obedeció, según las ocasiones, tanto al hecho de no haber utilizado sonido directo en la filmación, como a que los registros en los documentales políticos estaban marcados por la urgencia de la denuncia y por las condiciones clandestinas de su producción ${ }^{25}$.

A partir de México. La Revolución Congelada, Gleyzer puso en juego diversas técnicas del directo a la manera del Cinema Verité, asumiendo la forma de un modo de representación participativo, donde tanto los testimonios recogidos como el rol del realizador cumplen la función de presentar el mundo de manera mediatizada. Así, a través de la utilización del dispositivo de la entrevista, Gleyzer funge como agente catalizador de situaciones que apuntan a develar lo real allí donde el cine directo de observación mostraba limitaciones. Esta decisión guarda relación con el objetivo de dar fuerza a su tesis que gira en torno a la traición a los ideales subyacentes en la Revolución Mexicana ${ }^{26}$. Esto se ve claramente en el segundo episodio -rodado en la región de Chiapas donde se produce la planta del henequén. Allí, Gleyzer procura develar/denunciar la continuidad de las relaciones de explotación a la que los hacendados de la región someten al campesinado. Asimismo, recurre a la utilización de imágenes de archivo ${ }^{27}$ con una función informativa, que son seleccionadas e intercaladas con relación a los objetivos del relato. Raymundo Gleyzer apela pues a retratos de los líderes de la Revolución entre 1911 y 1917, puntualizando sus luces y sus sombras. La figura de Cárdenas, quien en la década del 30 avanzó en una serie de reformas de corte populista, carece de entidad en la trama. Este silenciamiento opera para reforzar su tesis acerca del entreguismo total del PRI desde la década de 1920. Allí se centran las críticas que Octavio Getino le formuló en 1973 cuando, siendo director del Ente de Calificación

\footnotetext{
25 Juana Sapire lo destaca para el caso de La Tierra Quema, Pictografías del Cerro Colorado y Ceramiqueros de Traslasierra, donde el sonido fue agregado en la postproducción.

${ }^{26}$ En su opinión, la misma había terminado absorbida por los intereses de la burguesía que, con la complicidad del PRI, acabó por relegar los intereses de los sectores populares.

${ }^{27}$ Salvo en la Tierra Quema, Gleyzer las utiliza en todos sus documentales aunque con fines diversos.
} 
Cinematográfica, le otorgó a Gleyzer el certificado de exhibición tras una larga etapa de censura al que el film había sido sometido²8.

La película, que recorre la campaña presidencial de Luis Echeverría en 1970, se cierra con escenas de la Masacre de Tlatelolco acaecida el 2 de octubre de 1968. En aquel contexto, el ahora candidato del PRI era miembro del gabinete del entonces presidente Gustavo Díaz Ordaz. En el montaje final, con el uso de las fotografías de la matanza mezcladas con la voz del Che apelando al carácter socialista que debía asumir toda Revolución, buscaba potenciar la denuncia y proyectar el llamado a la movilización. Finalmente, la voz over es central en el relato ya que opera como una instancia de saber absoluto que cumple la doble función de estructurar la trama y de vehiculizar la ideología subyacente en el film.

A partir de 1971 Raymundo Gleyzer despliega el sentido militante de su filmografía en Argentina. Los Comunicados del ERP29 (1971); Ni Olvido, Ni Perdón ${ }^{30}$ (1972-73) y Me matan si no trabajo y si trabajo me matan ${ }^{31}$ (1974), están marcados por la urgencia de difundir hechos políticamente significativos. Los dos primeros comparten la estructura argumentativa tradicional de planteo, desarrollo y conclusión con el fin de presentar el conflicto, describir los hechos y llamar a la acción. En la reconstrucción de estos documentales se utilizaron fotografías mezcladas con imágenes de reportajes televisivos recuperados y puestos al servicio del objetivo de contrainformar. Mientras los Comunicados del ERP interpelaban al pueblo con el fin de comunicarle las acciones de la organización, Ni Olvido, $\mathrm{Ni}$ Perdón constituyó un “film urgente”, que combinaba la denuncia de los

28 Getino percibía en la película cierta intencionalidad de desacreditar al populismo mexicano y, por elevación, al peronismo.

${ }^{29} \mathrm{El}$ comunicado $\mathrm{n}^{\circ} 2$ sobre el asalto al Banco Nacional de Desarrollo y los $\mathrm{n}^{\circ} 5$ y 7 sobre el secuestro del director del frigorífico Swift para intercambiarlo por comida, mantas y mejoras en las condiciones y medioambiente de trabajo. Véase: Peña y Vallina, 1998.

$3^{30}$ Sobre la Masacre de Trelew del 22 de agosto de 1972 cuando fusilaron a 16 de los 19 presos políticos fugados del Penal de Rawson el 15 de agosto. Fracasada su tentativa de abordar un avión con destino a Chile fueron recapturados y trasladados a la base aeronaval Almirante Zar en Trelew donde fueron asesinados. La Fuga del Penal de Rawson constituyó el primer operativo conjunto de las organizaciones armadas peronistas (Montoneros y FAR) y de la izquierda guevarista (ERP). Véase: Martinez, 1973 y Arruti, 1992

${ }^{31}$ Sobre la lucha contra las condiciones de explotación de los trabajadores de la fábrica INSUD, afectados por el saturnismo, enfermedad mortal que provoca la intoxicación por plomo en la sangre. 
fusilamiento de revolucionarios en una base aeronaval con el homenaje a los compañeros caídos en nombre de la revolución. En el mediometraje de 30' se utilizaron las imágenes de la Conferencia de Prensa completa de los evadidos realizada en el aeropuerto de Trelew, que había sido recuperada de un canal de la TV local. El documento, grabado originalmente en videotape, fue tomado de un monitor con una cámara de $16 \mathrm{~mm}$ para pasarlo a fílmico. Este proceso de remontaje se combinó con el montaje fotográfico de imágenes de los ejecutores, de los responsables políticos de la masacre y de las víctimas, mezcladas con entrevistas a los tres sobrevivientes y con imágenes de su liberación de la cárcel, diez meses más tarde, durante el llamado "Devotazo"32. Las mismas fueron compaginadas con carteles que configuraron la historia con un prólogo y un epílogo, mientras la voz over de Álvaro Melián ordenaba y conducía la trama. El film constituyó un llamado a la unidad de las organizaciones político-militares y del pueblo todo para luchar contra la dictadura y con el fin de constituir un nuevo orden social.

Los Traidores, película insignia del Cine de la Base es el resultado de la decisión del grupo de estructurar una denuncia sobre las características y prácticas de la burocracia sindical argentina. La idea había surgido a instancias de Joris Ivens quien, tras visionar los Comunicados políticos que habían filmado para el ERP, animó a Raymundo Gleyzer y a Álvaro Melián a avanzar sobre su proyecto de rodar una película sobre el tema. Desde ese encuentro de París, acaecido en 1971, los miembros del grupo empezaron a diseñar el proyecto. Si bien pensaron en hacer un documental, tras evaluar las dificultades para acceder o registrar imágenes, optaron por la ficción. Para elaborar el guion se basaron en el cuento La Víctima escrito por Víctor Proncet, quien encarnó al personaje protagónico de Barreda y fue además el responsable de la música del film. El elenco estaba compuesto tanto por actores profesionales como por otros provenientes del teatro independiente. Contaban con un presupuesto magro y toda la filmación se realizó en la clandestinidad. Si bien se trata eminentemente de un relato de carácter

${ }^{32}$ Se denominó "Devotazo" a la movilización para la liberación de todos presos políticos el 25 de mayo de 1973, día de la asunción del Presidente electo Héctor Cámpora que dio origen al tercer gobierno peronista. Véase: Arruti, 1992. 
ficcional, en la película anidan distintos registros y estilos que dan por resultado una suerte de hibridación donde las secuencias de ficción, en las que se utilizan recursos propios del cine de género, se mezclan con imágenes de archivo. Así lograron estructurar, a partir de un lenguaje llano, un film pregnante que cumplía con su objetivo central de llegar/interpelar a la base. Con la llegada de la dictadura y la desaparición de Gleyzer los miembros de Cine de la Base marcharon al exilio y el grupo se dispersó rápidamente. Sin embargo, antes de buscar nuevos rumbos, llegaron a filmar en el exterior los dos últimos documentales del grupo. Se trata de Las AAA son las tres armas realizada por el grupo exiliado en Perú, a partir de fragmentos de la Carta abierta de Rodolfo Walsh a la Junta Militar33 y de Persistir es vencer sobre la base de las entrevistas que Álvaro Melián y Jorge Giannoni le realizaron a dos importantes líderes perretistas en ocasión de la reunión del Comité Ejecutivo del PRT-ERP en Roma34. Ambos films datan de 1977.

\section{A modo de epílogo}

Si bien la sociedad argentina volvió al Estado de Derecho en 1983, Raymundo Gleyzer, al igual que muchos militantes por la causa revolucionaria, no tuvo en aquel contexto, imbuido por una memoria fragmentada y por la vigencia de la llamada Teoría de los dos Demonios35, el rescate que realmente merecía. Su compañero y amigo Jorge Denti, lo homenajeó de la mejor manera, a través del cine, al utilizar fragmentos de Nuestras Islas Malvinas en la que fuera su ópera prima, el documental Malvinas Historia de Traiciones (1984) ${ }^{36}$.

\footnotetext{
33 Fechada el 24 de marzo de 1977, a un año del golpe y un día antes de su desaparición.

34 Los entrevistados fueron Enrique Gorriarán Merlo y Luis Mattini.

35 A partir del gobierno de Raúl Alfonsín, primer presidente de la transición democrática, se denomina «teoría de los dos demonios» a aquella concepción que interpreta que, durante los años setenta, Argentina estuvo envuelta en un clima de violencia política provocado por dos extremos ideológicos, por «dos demonios»: la extrema derecha, a través del Estado terrorista, y la extrema izquierda, a través de la violencia revolucionaria. Esta interpretación se instaló como relato y explicación dominante de la época y logró un amplio consenso en la opinión pública a partir de su incorporación en el prólogo del libro Nunca Más de la CONADEP, editado en 1984.

${ }^{36}$ Las imágenes tomadas por Gleyzer en Malvinas en aquel lejano 1966 fueron utilizadas por Federico Urioste, como parte del documental Hundan al Belgrano, treinta años después. Sin embargo, Raymundo Gleyzer no apareció en los créditos porque el realizador, que había
} 
La política de derechos humanos del gobierno de Raúl Alfonsín, que se limitó a juzgar a las Juntas de Comandantes37, operó en una sociedad en parte anestesiada, en parte disciplinada por los años de dictadura. El malestar castrense frente a los juicios y los levantamientos militares carapintadas, dieron sustento a la sanción de las leyes de Punto Final ${ }^{8}$ y Obediencia Debida39. Las mismas, junto a los indultos presidenciales otorgados a los genocidas condenados durante el gobierno de Carlos Menem ${ }^{40}$, clausuraron por más de quince años las condiciones de posibilidad de hacer efectivas las demandas de Memoria, Verdad y Justicia.

Mientras muchos/muchas argentinos/argentinas seguían luchando contra el olvido, Juana Sapire cuidaba la obra de Raymundo como el tesoro más preciado. Gracias a la copia que circulaba en VHS de Los Traidores en la ya mítica videoteca Liberarte, los cinéfilos argentinos podían asomarse a su film más emblemático. Con la crisis del 19 y 20 de diciembre de 2001, en el marco de las movilizaciones populares, se produjo un rescate del documentalismo de denuncia sociopolítica y muchos cineastas salieron nuevamente a filmar la urgencia. Allí sobrevolaba el espíritu de los grupos de cineastas militantes de los años sesenta y setenta.

En 2003, gracias a la realización del film Raymundo de Ernesto Ardito y Virna Molina, su obra y su memoria comenzaron a ser rescatadas/recuperadas. En ese contexto, el gobierno Nestor Kirchner avanzó

conseguido el material en una agencia de publicidad, no supo hasta mucho después quien lo había filmado.

37 El Juicio a las Juntas Militares, realizado entre abril y diciembre de 1985, generó uno de los fallos más importantes de la historia de la justicia argentina y latinoamericana. Los dictadores Jorge Rafael Videla y Emilio Eduardo Massera fueron condenados a reclusión perpetua; Roberto Eduardo Viola fue condenado a 17 años de prisión; Armando Lambruschini a 8 años; Orlando Ramón Agosti a 4 años y 6 meses. El resto de los comandantes resultaron absueltos.

${ }^{38}$ Sancionada el 31 de diciembre de 1986, tuvo como objetivo la fijación de una fecha tope para la presentación de causas asociadas a la represión ilegal.

39 En respuesta a las demandas derivadas del movimiento carapintada de "Semana Santa", fue enviada al Congreso el 13 de mayo de 1987. La ley tenía su base en el "Acta de Compromiso Democrático" que los representantes de los principales partidos habían suscripto en forma conjunta el 19 de abril de aquel año, estableciendo distintos niveles de responsabilidad entre los represores.

${ }^{40}$ El primer indulto del 8 de octubre de 1989 favoreció a un nutrido número de procesados y condenados. El segundo indulto dictado a fines de diciembre del siguiente año alcanzó a los miembros de las dos primeras juntas militares como así también a los principales dirigentes de la organización guerrillera Montoneros. 
sobre la anulación de las leyes del perdón ${ }^{41}$, posibilitando la reapertura de los juicios por la Memoria, la Verdad y la Justicia. El 30 de agosto de 2010, en el marco de la Megacausa Primer Cuerpo De Ejército42, en la que se investigaban los hechos sucedidos en el centro de clandestino de detención $E l$ Vesubio, Juana Sapire declaró en el juicio por la desaparición de Raymundo Gleyzer43. Finalmente, el 18 de diciembre de 2014, a más de 38 años de su desaparición, el Tribunal Oral Federal 4 de Capital dictó la sentencia condenando a los responsables. En honor a su memoria distintas agrupaciones de documentalistas de Argentina han tomado la fecha de su desaparición, el 27 de mayo, como el día del documentalista, un más que merecido homenaje para quien fuera, hasta el último aliento, un hombre coherente y comprometido con las causas populares.

\section{Referencias bibliográficas}

Carnovale, V. (2011). Los combatientes. Historia del PRT - ERP. Buenos Aires: Siglo XXI.

De la Puente, M. (2007). Estética y política en el cine militante argentino actual, (en línea) Disponible en: http://perio.unlp.edu.ar/ojs/index.php/question/article/view/358/29 o

Getino, O. (1998). Cine argentino. Entre lo posible y lo deseable. Buenos Aires: Ciccus.

Gleyzer, R. (1970). Presentación y autocrítica en forma de diálogo con Tomás Gutiérrez Alea. (en línea), Disponible en http://www.docacine.com.ar/articulos/gutierrez.htm

${ }^{41}$ Fue durante el Kirchnerismo (2003 -2015) que el Estado argentino respondió por primera vez, de forma clara y sostenida, a las demandas de los organismos de Derechos Humanos. En ese contexto los juicios a los responsables del terrorismo de Estado se reiniciaron. Para ello, era indispensable derogar las leyes del perdón y encontrar un mecanismo que permitiera devolver a los indultados a la cárcel. Dado que el indulto reviste el carácter de "perdón presidencial" había que volver a llevarlos a juicio. Sin embargo, como nadie puede ser juzgado dos veces por el mismo delito, era necesario encontrar algún resquicio, delitos que no hubieran sido juzgado previamente. Los abogados y abogadas de HIJOS lo hallaron: la apropiación ilegal de menores, delito este que no había sido tenido en cuenta en los juicios de los años 8o. Así, Videla y Massera terminaron sus vidas presos, al tiempo que comenzó todo un proceso judicial por la Memoria, la Verdad y la Justicia, largamente postergado.

42 Incluía la investigación de los crímenes cometidos en los centros clandestinos de detención "Mansión Seré", "Vesubio", "Atlético, Banco y Olimpo" y "Automotores Orletti", así como también por el caso de "Masacre de Fátima" (vinculada con la aparición de 30 cadáveres en la localidad bonaerense de Fátima, provincia de Buenos Aires, el 20 de agosto de 1976).

43 Donde fueron asesinados, además de Gleyzer, los escritores Haroldo Conti y Héctor Oesterheld. 
Gonzalez Janzen, I. (1986). La triple A. Buenos Aires: Contrapunto.

Gutman, D. (2003). Tacuara. Historia de la primera guerrilla urbana argentina. Buenos Aires: Vergara.

Longoni, A. (2006). El Fatrac: frente cultural del PRT-ERP. Lucha Armada en la Argentina. Buenos Aires, Año 2, $\mathrm{N}^{0} 4$.

Martínez, T.E. (1973). La Pasión según Trelew. Buenos Aires: Planeta.

Metsman, M. (1993). Aproximaciones a una experiencia de cine militante (Argentina 1968-1973). (en línea) Disponible en: http://www.caia.org.ar/docs/21_Mestman.pdf

Metsman, M (2001a). Postales del cine militante argentino en el mundo, (en línea) Disponible en: https://issuu.com/rehime/docs/mestman__m._2001_postales_de 1 cin

Metsman, M (2001b). La exhibición del cine militante. Teoría y práctica en el Grupo Cine Liberación, (en línea) Disponible en: http://www.panoramadelarte.com.ar/archivos/Tercer\%20Cine.pdf

Metsman, M. (2016). Las rupturas del 68 en el cine de América Latina. Buenos Aires: Akal.

Monterde Lozaya, J.E (2016). Artes en Pantalla. El cine como dispositivo crítico. Barcelona: FUOC.

Nichols, B. (1997). La representación de la realidad. Cuestiones y conceptos sobre el documental. Barcelona: Paidós.

Ortega, M.L et al, (2008). Cine Directo. Reflexiones en torno a un concepto. Madrid: T\&B.

Peña, F. y Vallina, C. (1998). El cine como arma. Raymundo Gleyzer y los comunicados del E.R.P. (1971-1972), Razón y Revolución No 4, (en línea), Disponible en: http://www.razonyrevolucion.org/textos/revryr/arteyliteratura/ryr4P ena.pdf

Peña, F. y Vallina, C. (2006). El cine quema. Raymundo Gleyzer. Buenos Aires: De la Flor.

Sapire, J. y Sabat, C. (2017). Compañero Raymundo. Buenos Aires: Sudestada.

Seoane, M. (1997). Todo o Nada. La historia secreta y la historia pública del jefe guerrillero Mario Roberto Santucho. Buenos Aires: Planeta.

Stam, R (2001). Teorías del cine. Una introducción. Barcelona: Paidós.

\section{Filmografía}

Ardito, E y Molina, V, Raymundo, 2003.

Ardito, E y Molina, V, Memoria Iluminada. Raymundo Gleyzer, 2011.

Arruti, M, Trelew. La fuga que fue masacre, 1992.

Gleyzer, R, El Ciclo, ¿1963?

Gleyzer, R, La Tierra Quema, 1964.

Gleyzer, R, Pictografías del Cerro Colorado, 1965

Gleyzer, R, Ceramiqueros de Traslasierra, 1965 
Gleyzer, R y Prelorán J, Ocurrido en Hualfin, 1965.

Gleyzer, R y Prelorán, J, Quilino, 1966,

Gleyzer, R, Nuestras Islas Malvinas, 1966.

Gleyzer, R, Nota sobre Cuba, 1969

Gleyzer, R, México. La Revolución Congelada, 1970.

Cine de la Base, Comunicados 2, 5 y 7 del ERP, 1971.

Cine de la Base, Ni olvido ni perdón: 1972, la masacre de Trelew, 1972.

Cine de la Base, Los Traidores, 1973.

Cine de la Base. Me matan si no trabajo y si trabajo me matan: La huelga obrera en la fábrica INSUD, 1974.

Cine de la Base, Las AAA son las tres Armas, 1977.

Cine de la Base, Persistir es vencer, 1977. 